\title{
URBANIZATION CHALLENGE: SOLID WASTE MANAGEMENT IN SYLHET CITY, BANGLADESH
}

\author{
Sabrin Ara \\ Lecturer, \\ Department of Civil and \\ Environmental Engineering, \\ Shahjalal University of Science and \\ Technology, Sylhet 3114, Bangladesh
}

\author{
Rabea Khatun \\ Graduate student, \\ Department of Civil and \\ Environmental Engineering, \\ Shahjalal University of Science and \\ Technology, Sylhet 3114, \\ Bangladesh
}

\author{
Mohammad Salah Uddin \\ Graduate student, \\ Department of Civil and \\ Environmental Engineering, \\ Shahjalal University of Science and \\ Technology, Sylhet 3114, \\ Bangladesh
}

\begin{abstract}
In the rush towards urbanization as well as with emerging consumption, many developing countries have witnessed the overflow of waste and depletion of the inexhaustible natural resources at an alarming rate. As wastes are the outgrowth of the urban system, the urban dynamics influence the quantity, types and management of waste. The purpose of this study is to estimate the amount of the generated wastes from 2002 to 2017 with the urban growth of Sylhet city and implement the 3R (recycling, reuse, refuse) strategy conceptually for maximizing resource recovery and reducing landfilling. In this study, solid waste generation and it's composition is estimated by collecting data through interviews encompassing 300 units from the representative areas and direct field survey. Correlation test between population and solid waste has been performed to measure the strength of association. The result indicated that, in 15 years, waste generation has increased 170 tons which calls for better management. From the study it is shown that about $72.46 \%(188.396$ tons) of the waste can be minimized by executing 3Rs leaving only $27.54 \%$ to be dumped into landfill. It is evident that, implementation of the 3Rs will have a profound impact to protect the environment.
\end{abstract}

Keywords-Correlation, Pollution, Solid Waste, Urbanization, 3Rs (recycling, reuse, refuse)

\section{INTRODUCTION}

"Waste is the evidence that we are doing something wrong. Landfills simply bury the evidence and incinerators (by whatever fancy name they are called) simply burn the evidence" [1]

Though urbanization is inevitable for the development of our country, the rapid urban growth has dispensed heavy pressures on land and resources and resulted in serious environmental problems. Urbanization is influenced by the aptitude that cities and towns have better economic, social and political advantages than the rural areas. With the prompt increase in population and unplanned urbanization, many developing countries including Bangladesh, are facing a colossal challenge of managing municipal solid waste [2]. Both the rise in population and increase in per capita waste generation, have reflected that, by 2025 this amount will reach almost 47,000 tons/day and nearly 17.2 million tons per year [3]. Disposal in landfills is still the most common destination, but shortage of land for landfills is a physical constraint. Moreover, urban development is replacing undeveloped land causing the bare lands to be filled up leaving no suitable space for using as landfills. Migration from the stagnant and low paying rural areas to the more paying urban area for better lifestyle has incited the increase in types and amount of solid wastes in and around Sylhet city. Again, improper solid waste management (SWM) is one of the most burning environmental problems in Bangladesh, hence solid waste disposal is a challenging issue for a fast-growing city like Sylhet [4]. Again the illegally dumped uncollected waste in open spaces, water bodies or even burnt on the street and roadsides, ascending serious threat to environment [5].

Sylhet city corporation (SCC) is becoming a concrete jungle and fading its greenery day by day due to the unplanned and improper urbanization with increasing waste stream. Being not an industrial city, most of the generated wastes here are of domestic, commercial and clinical type and these are increasing with the growth of urban system. Again, a total number of nine natural drainage channels (locally called Chara) [6] are being filled up by the wastes from most of the households (situated along or near the Chara) as well as the street sweeping, which eventually affects the natural drainage system and the environment. Also, at Lalmatia, a low-lying land in Mogla bazar, wastes are disposed in an uncontrolled manner causing blockage of drains resulting in localized flooding and unhygienic condition. Here, SCC is the only responsible organization for the management of solid waste though some community-based organizations (CBOs), Non- 
Governmental Organizations (NGOs) and private sectors are also working. Though SCC has taken initiatives to manage solid wastes by collecting, transporting and disposing, these practices are being challenged due to the uncontrolled collection system, inadequate space and increasing value of land. In the existing Solid Waste Management (SWM) system undertaken by SCC, some notified problems are:

$\checkmark$ Inadequate service coverage,

$\checkmark$ Operational inefficiencies of services,

$\checkmark$ Improper management of clinical (hazardous) waste. Again, the Lalmatia landfill is going to be completely filled up requiring the selection of new landfill sites. But new landfill site acquisition is so uncertain due to the NIMBY (not in my back yard), BANANA (build absolutely nothing anywhere near anything), LULU (locally unacceptable land use) and NOTE (not over there either) syndrome [7] in the local community. The increasing rate of solid waste has a hostile effect on the environment as well as social and professional life of the city dweller and urban planners. Treating waste as a resource is the first step towards waste management and conserving resources [8]. Therefore, an approach to implementation of 3Rs (recycling, reuse, refuse) will have an inferential efficiency in managing and lessening the waste hazard. So, this study intends to develop the concept of 3Rs order to solve the existing problems of solid waste management in Sylhet city like requirement of sites for landfill, overburden of increased amount of solid waste, cost of management, health and hygiene and finally detrimental environmental and sanitary conditions. In addition, it will also help to solve the unemployment problem by involving the poor people in resource recovery operations.

\section{A. Background Study}

This study aims at assessing the correlation between population, urban growth and solid waste in Sylhet city and recommending proper approach to minimize the waste stream. Recently, a lot of studies have been conducted on these issues. A little of the studies are emphasized in table 1.

Table 1. Summary of the literature reviewed for this study.

Study on correlation of urbanization with population and solid waste

\begin{tabular}{|l|l|l|l|}
\hline Year & Study & Reference & Focus \\
\hline 1999 & $\begin{array}{l}\text { Concluded that the } \\
\text { increasing population } \\
\text { leads to swelling the } \\
\text { waste generation, again } \\
\text { built up environment } \\
\text { arrangement influences } \\
\text { the waste management. }\end{array}$ & $\begin{array}{l}\text { Correlating } \\
\text { population } \\
\text { and built up } \\
\text { environment } \\
\text { with solid } \\
\text { waste }\end{array}$ \\
\hline 2001 & $\begin{array}{l}\text { Explored he dynamic } \\
\text { interrelation between the } \\
\text { urban system and the } \\
\text { waste management }\end{array}$ & & $\begin{array}{l}\text { Urban system } \\
\text { and waste } \\
\text { management }\end{array}$ \\
\hline
\end{tabular}

\begin{tabular}{|c|c|c|c|}
\hline & system. & & \\
\hline 2007 & $\begin{array}{l}\text { Studied on correlation } \\
\text { between various type of } \\
\text { population related } \\
\text { variables and waste } \\
\text { related variables. }\end{array}$ & [11] & $\begin{array}{l}\text { Population } \\
\text { and waste }\end{array}$ \\
\hline 2011 & $\begin{array}{l}\text { Identified the } \\
\text { inappropriate solid waste } \\
\text { disposal system as a } \\
\text { major environmental } \\
\text { problems due to rapidly } \\
\text { increased population and } \\
\text { unplanned urbanization } \\
\text { in Sylhet. }\end{array}$ & [12] & $\begin{array}{l}\text { Population, } \\
\text { urbanization, } \\
\text { solid waste } \\
\text { generation }\end{array}$ \\
\hline 2012 & $\begin{array}{l}\text { Worked on the } \\
\text { urbanization induced } \\
\text { solid waste management } \\
\text { in India to see the } \\
\text { upcoming trends of } \\
\text { urbanization and } \\
\begin{array}{l}\text { accordingly generation } \\
\text { of waste. }\end{array}\end{array}$ & [13] & $\begin{array}{l}\text { Urbanization, } \\
\text { waste } \\
\text { generation }\end{array}$ \\
\hline 2014 & $\begin{array}{l}\text { Studied to examine the } \\
\text { aftereffect of unplanned } \\
\text { urbanization on } \\
\text { environment in Sylhet } \\
\text { City Corporation (SCC). }\end{array}$ & [14] & $\begin{array}{l}\text { Urbanization } \\
\text { and } \\
\text { environmental } \\
\text { problems }\end{array}$ \\
\hline 2015 & $\begin{array}{l}\text { Investigated the solid } \\
\text { waste management in } \\
\text { the Bolgatanga } \\
\text { municipality of the } \\
\text { upper East region, } \\
\text { Ghana to show that the } \\
\text { increasing urban } \\
\text { population had a } \\
\text { negative impact on } \\
\text { waste management. }\end{array}$ & [15] & $\begin{array}{l}\text { Population } \\
\text { and waste } \\
\text { generation }\end{array}$ \\
\hline 2016 & $\begin{array}{l}\text { Studied to understand } \\
\text { how the residential land } \\
\text { use and associated } \\
\text { activities in a } \\
\text { small/medium scale } \\
\text { urban area are related to } \\
\text { the quantity of generated } \\
\text { waste, in South India } \\
\text { (three cities- } \\
\text { Thiruvananthapuram, } \\
\text { Coimbatore and } \\
\text { Kozhikode). }\end{array}$ & [16] & $\begin{array}{l}\text { Land use } \\
\text { based } \\
\text { modelling of } \\
\text { solid waste } \\
\text { generation }\end{array}$ \\
\hline \multicolumn{4}{|c|}{$\begin{array}{l}\text { Study on solid waste management and options outside } \\
\text { Bangladesh }\end{array}$} \\
\hline 2003 & $\begin{array}{l}\text { Pointed composting as a } \\
\text { feasible pretreatment } \\
\text { process of solid waste } \\
\text { before going to the }\end{array}$ & [17] & $\begin{array}{l}\text { Solid waste } \\
\text { management, } \\
\text { Recycling } \\
\text { (composting) }\end{array}$ \\
\hline
\end{tabular}




\begin{tabular}{|c|c|c|c|}
\hline & disposal site. & & \\
\hline 2006 & $\begin{array}{l}\text { Studied the problems, } \\
\text { issues and challenges } \\
\text { regarding the municipal } \\
\text { solid waste management } \\
\text { was studied in the } \\
\text { Southern Province of Sri } \\
\text { Lanka. }\end{array}$ & [18] & $\begin{array}{l}\text { Solid waste } \\
\text { management, } \\
\text { Resource } \\
\text { recovery }\end{array}$ \\
\hline 2006 & $\begin{array}{l}\text { Made general overview } \\
\text { of current solid waste } \\
\text { management practices in } \\
\text { Çorlu Town of Turkey. }\end{array}$ & [19] & $\begin{array}{l}\text { Solid waste } \\
\text { management, } \\
\text { recycling }\end{array}$ \\
\hline 2007 & $\begin{array}{l}\text { Attempted to give a } \\
\text { picture of the ongoing } \\
\text { 3R implementation in } \\
\text { urban municipal solid } \\
\text { waste management in } \\
\text { Asian countries. }\end{array}$ & [7] & $\begin{array}{l}\text { Solid waste } \\
\text { management, } \\
\text { 3Rs }\end{array}$ \\
\hline 2009 & $\begin{array}{l}\text { Studied on the municipal } \\
\text { solid waste management } \\
\text { in Kolkata (India) and } \\
\text { reported the availability } \\
\text { of different recyclable } \\
\text { items at the Dhapa } \\
\text { dumping ground, with } \\
\text { corresponding market } \\
\text { prices. }\end{array}$ & [20] & $\begin{array}{l}\text { Solid waste } \\
\text { management, } \\
\text { Recycling }\end{array}$ \\
\hline 2009 & $\begin{array}{l}\text { Identified that recycling } \\
\text { is one form of } \\
\text { sustainable solid waste } \\
\text { management. }\end{array}$ & [21] & $\begin{array}{l}\text { Solid waste } \\
\text { management, } \\
\text { Recycling }\end{array}$ \\
\hline 2009 & $\begin{array}{l}\text { Conducted a research to } \\
\text { find out the evolution of } \\
\text { solid waste management } \\
\text { in Malaysia. }\end{array}$ & [22] & $\begin{array}{l}\text { Solid waste } \\
\text { management, } \\
\text { Recycling }\end{array}$ \\
\hline 2009 & $\begin{array}{l}\text { Aimed at evaluating the } \\
\text { generation, } \\
\text { characteristics, and } \\
\text { management of solid } \\
\text { waste in Malaysia. }\end{array}$ & [23] & $\begin{array}{l}\text { Solid waste } \\
\text { management, } \\
\text { 3Rs }\end{array}$ \\
\hline 2010 & $\begin{array}{l}\text { Conducted a study in } \\
\text { Prince George campus } \\
\text { of the University of } \\
\text { Northern British } \\
\text { Columbia (UNBC) and } \\
\text { observed the three most } \\
\text { significant material types } \\
\text { for targeted waste } \\
\text { reduction and recycling } \\
\text { efforts. }\end{array}$ & [24] & $\begin{array}{l}\text { Solid waste } \\
\text { management, } \\
\text { reduction and } \\
\text { recycling }\end{array}$ \\
\hline 2011 & $\begin{array}{l}\text { Studied to compare the } \\
\text { current situation, } \\
\text { historical background, } \\
\text { and effectiveness of } 3 R\end{array}$ & {$[25]$} & $\begin{array}{l}\text { Solid waste } \\
\text { management, } \\
\text { 3Rs }\end{array}$ \\
\hline
\end{tabular}

\begin{tabular}{|c|c|c|c|}
\hline & $\begin{array}{l}\text { policies within one } \\
\text { region [the European } \\
\text { Union (EU)] and five } \\
\text { countries (USA, Korea, } \\
\text { Japan, China, and } \\
\text { Vietnam. }\end{array}$ & & \\
\hline 2012 & $\begin{array}{l}\text { Aimed at making people } \\
\text { aware of the 3Rs culture, } \\
\text { in particular, university } \\
\text { students (International } \\
\text { Islamic University } \\
\text { Malaysia). }\end{array}$ & {$[26]$} & $\begin{array}{l}\text { Solid waste } \\
\text { management, } \\
\text { 3Rs }\end{array}$ \\
\hline 2015 & $\begin{array}{l}\text { Worked to assess the } \\
\text { municipal solid waste } \\
\text { management in relation } \\
\text { to 3Rs strategy in Wa, } \\
\text { Ghana. }\end{array}$ & $\begin{array}{l}{[27]} \\
\end{array}$ & $\begin{array}{l}\text { Solid waste } \\
\text { management, } \\
\text { 3Rs }\end{array}$ \\
\hline 2017 & $\begin{array}{l}\text { Carried out the } \\
\text { characterization and the } \\
\text { trend of solid waste } \\
\text { generated in University } \\
\text { of Lagos, Nigeria and } \\
\text { revealed that, recyclable } \\
\text { potential of the waste is } \\
\text { very high ( } 75 \% \text { of the } \\
\text { total waste generated) in } \\
\text { the University campus. }\end{array}$ & $\begin{array}{l}{[28]} \\
\end{array}$ & $\begin{array}{l}\text { Waste } \\
\text { management } \\
\text { option, } \\
\text { recycling. }\end{array}$ \\
\hline 2017 & $\begin{array}{l}\text { Studied on the waste } \\
\text { disposal practices by } \\
\text { residents of various } \\
\text { types of dwellings in } \\
\text { Dharwad rad city } \\
\text { (Karnataka, southern } \\
\text { India). }\end{array}$ & $\begin{array}{l}{[29]} \\
\end{array}$ & $\begin{array}{l}\text { Solid waste } \\
\text { management, } \\
\text { 3Rs }\end{array}$ \\
\hline 2017 & $\begin{array}{l}\text { Evaluated } \\
\text { sustainability } \\
\text { effectiveness of the } \\
\text { municipal solid waste } \\
\text { management system in } \\
\text { Bangkok. }\end{array}$ & $\begin{array}{l}{[30]} \\
\end{array}$ & $\begin{array}{l}\text { Solid waste } \\
\text { management, } \\
\text { 3Rs }\end{array}$ \\
\hline \multicolumn{4}{|c|}{$\begin{array}{l}\text { Study on solid waste management and options outside } \\
\text { Bangladesh }\end{array}$} \\
\hline 2009 & $\begin{array}{l}\text { A thesis work was } \\
\text { conducted } \\
\text { recommending the usage } \\
\text { of Rs to minimize the } \\
\text { solid waste taking in } \\
\text { consideration the entire } \\
\text { country of Bangladesh. }\end{array}$ & $\begin{array}{l}{[31]} \\
\end{array}$ & $\begin{array}{l}\text { Solid waste } \\
\text { management, } \\
\text { Rs }\end{array}$ \\
\hline 2012 & $\begin{array}{l}\text { Investigated the current } \\
\text { disposal system of } \\
\text { clinical waste and also } \\
\text { the waste management } \\
\text { system of Sylhet City } \\
\text { Corporation (SCC). }\end{array}$ & $\begin{array}{l}{[32]} \\
\end{array}$ & $\begin{array}{l}\text { Solid waste } \\
\text { management, } \\
\text { recycling }\end{array}$ \\
\hline
\end{tabular}




\begin{tabular}{|c|c|c|c|}
\hline 2013 & $\begin{array}{l}\text { Detailed the technical } \\
\text { and methodical issues of } \\
\text { solid waste management } \\
\text { as well as the non- } \\
\text { technical and specific } \\
\text { management of solid } \\
\text { waste. }\end{array}$ & [33] & $\begin{array}{l}\text { Solid waste } \\
\text { management, } \\
\text { Rs }\end{array}$ \\
\hline 2013 & $\begin{array}{l}\text { Reviewed the amount of } \\
\text { recovery and recycling } \\
\text { of wastes in Chittagong } \\
\text { city and recommended } \\
\text { for promoting 3R } \\
\text { strategy in waste } \\
\text { minimization. }\end{array}$ & [34] & $\begin{array}{l}\text { Solid waste } \\
\text { management, } \\
\text { 3Rs }\end{array}$ \\
\hline 2013 & $\begin{array}{l}\text { Explored people's } \\
\text { perception on adopting } \\
\text { 3Rs concept for Solid } \\
\text { Waste Management } \\
(\text { SWM }) \text { in Chittagong, } \\
\text { Bangladesh. }\end{array}$ & [35] & $\begin{array}{l}\text { Solid waste } \\
\text { management, } \\
\text { 3Rs }\end{array}$ \\
\hline 2014 & $\begin{array}{l}\text { Emphasized that 3Rs } \\
\text { approach can promote } \\
\text { the efficient use of } \\
\text { resources, harmonizing } \\
\text { both environmental and } \\
\text { economic concerns } \\
\text { through making efforts } \\
\text { on waste reduction, } \\
\text { reuse and recycling in } \\
\text { Bangladesh. }\end{array}$ & {$[36]$} & $\begin{array}{l}\text { Solid waste } \\
\text { management, } \\
\text { 3Rs }\end{array}$ \\
\hline 2014 & $\begin{array}{l}\text { Developed the } 3 \mathrm{R} \\
\text { strategy for waste } \\
\text { management in the } \\
\text { urban areas } \\
\text { Bangladesh. }\end{array}$ & [37] & $\begin{array}{l}\text { Solid waste } \\
\text { management, } \\
\text { 3Rs }\end{array}$ \\
\hline 2016 & $\begin{array}{l}\text { Studied solid waste } \\
\text { management in Dhaka } \\
\text { city and stated that, } \\
\text { recycling can solve the } \\
\text { unemployment problem } \\
\text { as well as offering an } \\
\text { admirable environment. }\end{array}$ & {$[38]$} & $\begin{array}{l}\text { Solid waste } \\
\text { management, } \\
\text { recycling }\end{array}$ \\
\hline 2017 & $\begin{array}{l}\text { Revised the solid waste } \\
\text { management Practice in } \\
\text { Dhaka City and } \\
\text { emphasized on resource } \\
\text { recovery. }\end{array}$ & [39] & $\begin{array}{l}\text { Solid waste } \\
\text { management, } \\
\text { resource } \\
\text { recovery }\end{array}$ \\
\hline 2017 & $\begin{array}{l}\text { Conducted a research } \\
\text { work on municipal solid } \\
\text { waste management bin } \\
\text { Sylhet city, Bangladesh } \\
\text { and showed thenegative } \\
\text { imp.act of poor solid } \\
\text { waste management in } \\
\text { SCC. }\end{array}$ & {$[40]$} & $\begin{array}{l}\text { Solid waste } \\
\text { management, } \\
\text { 3Rs }\end{array}$ \\
\hline
\end{tabular}

\begin{tabular}{|l|l|l|l|}
\hline 2018 & $\begin{array}{l}\text { Reviewed the solid } \\
\text { waste management } \\
\text { process and impacts on } \\
\text { the environment and } \\
\text { living species due to } \\
\text { solid waste in Sylhet } \\
\text { City Corporation, } \\
\text { Bangladesh. }\end{array}$ & $\begin{array}{l}\text { Solid waste } \\
\text { management }\end{array}$ \\
\hline 2018 & $\begin{array}{l}\text { Studied the challenges of } \\
\text { solid waste management } \\
\text { in Sylhet City } \\
\text { Corporation. }\end{array}$ & $\begin{array}{l}\text { Solid waste } \\
\text { management }\end{array}$ \\
\hline
\end{tabular}

\section{STUDY AREA}

The study area for this research is Sylhet City Corporation (SCC) which is situated in the Sylhet Division, Bangladesh. SCC consists of 27 wards and 210 mahallas, and has a total area of $26.50 \mathrm{~km}^{2}$. In this study, 16 wards were taken as representative as shown in Fig. 1. These wards were selected according to their land use pattern, population, household and area. A brief description of these wards is given in the table 2 .

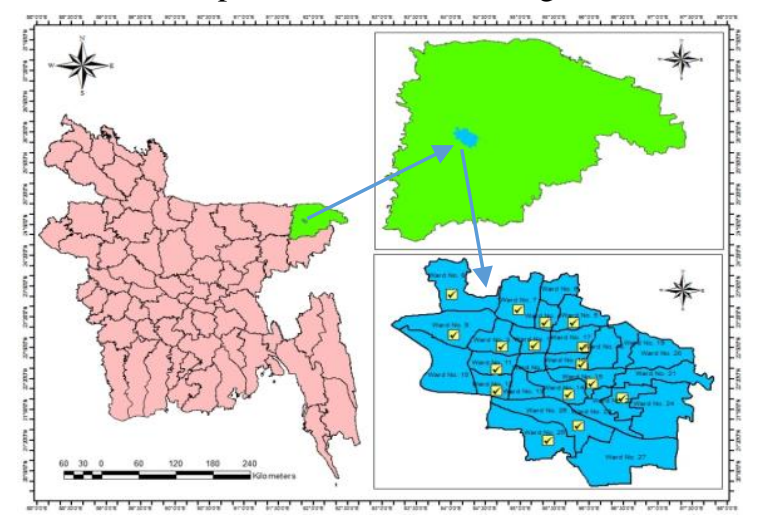

Fig. 1: Map showing the study area.

\section{METHODOLOGY}

Data were collected in order to estimate the waste generation rate and to examine the composition of the generated wastes. Also, correlation analysis between population and solid waste has been performed after collecting data. Finally wastes have been sorted to determine the percentages that can be managed by implementing the 3Rs (Reduce, Reuse, Recycle). By the time, the existing management system of solid waste and practice of using Rs have also been assessed to meet the aim of this study by recording the views of the respondents. Then data have been analyzed and findings have been made.

Table 2: Description of the selected wards

\begin{tabular}{|l|c|c|c|}
\hline $\begin{array}{l}\text { Ward } \\
\text { selected }\end{array}$ & Population $^{*}$ & Household & Land use type \\
\hline Ward 1 & 11781 & 2143 & Mostly residential \\
\hline
\end{tabular}




\begin{tabular}{|c|c|c|c|}
\hline Ward 3 & 15229 & 2800 & $\begin{array}{l}\text { Residential and } \\
\text { clinical }\end{array}$ \\
\hline Ward 4 & 10919 & 2269 & $\begin{array}{c}\text { Residential and } \\
\text { commercial }\end{array}$ \\
\hline Ward 5 & 21982 & 4206 & Residential \\
\hline Ward 7 & 29726 & 5906 & Residential \\
\hline Ward 8 & 28194 & 6069 & Residential \\
\hline Ward 9 & 27475 & 5159 & $\begin{array}{c}\text { Residential, } \\
\text { commercial and } \\
\text { institutional }\end{array}$ \\
\hline Ward 11 & 18668 & 3752 & $\begin{array}{c}\text { Residential, } \\
\text { commercial and } \\
\text { clinical }\end{array}$ \\
\hline Ward 12 & 14184 & 2656 & Residential \\
\hline Ward 14 & 17044 & 3679 & $\begin{array}{c}\text { Commercial, } \\
\text { residential. }\end{array}$ \\
\hline Ward 15 & 19076 & 3826 & $\begin{array}{c}\text { Commercial, } \\
\text { residential }\end{array}$ \\
\hline Ward 16 & 14845 & 3554 & Residential \\
\hline Ward 17 & 19506 & 3939 & $\begin{array}{c}\text { Residential and } \\
\text { commercial }\end{array}$ \\
\hline Ward 22 & 15799 & 3231 & $\begin{array}{l}\text { Residential, } \\
\text { institutional }\end{array}$ \\
\hline Ward 25 & 15106 & 2864 & $\begin{array}{l}\text { Commercial and } \\
\text { residential }\end{array}$ \\
\hline Ward 26 & 19997 & 3831 & $\begin{array}{l}\text { Commercial and } \\
\text { residential }\end{array}$ \\
\hline
\end{tabular}

"Population and household data (census 2011)

\section{A. Data Collection}

A semi-structured questionnaire with open-ended and closeended questions has been designed, pre-tested and modified to the final shape for data collection.

\section{A (a). Primary Data Collection}

This includes pilot study and field study. In pilot study, the wards from which data would be collected and the sampling size have been reviewed and field study has been conducted in those selected area.

\section{Pilot Study}

For this study, the desired sample size was estimated by using the statistical formula for sample size determination by M.Nurul Islam [43]. Using a margin of error of 0.06 with a $95 \%$ confidence level and sample frame of about 60,000 households (in SCC), 300 units (including households, institutions, hospitals, restaurants, shops etc.) were estimated as the sample size for the socio-economic survey.

\section{Field Study}

The field study, was conducted, using stratified random sampling method representing the 16 wards selected in the pilot study and 300 households with a total population of 1476. Some household data were collected in March 2017 and the rest were collected between October 2017 to November
2017. Survey by questionnaire was conducted to collect required data. Also, formal and informal interviews were taken along with identification of problems, efficiency and limitation of the existing management system.

\section{A (b). Secondary Data Collection}

Secondary data have been collected from SCC conservancy wings, related NGOs and published papers.

\section{B. Data Analysis and Waste Generation Rate}

From 16 wards 300 households were taken as sample consisting a population of 1476 . The collected data has been overviewed to estimate the waste generation rate.

\section{Correlation Test and Trend Analysis}

The correlation test was made out in order to determine the association between population and solid waste. The Pearson correlation coefficient (PCC) (also referred to as Pearson's r or the bivariate correlation) has been calculated which is a measure of linear correlation between the variables.

\section{Examination of Waste Composition}

To review the composition of waste, 3 representative samples of $100 \mathrm{~kg}$ waste from 3 different waste collection trucks were taken to examine the waste composition. The average weight of the waste content was estimated.

\section{E. Waste Sorting According to 3Rs}

3 representative samples of $100 \mathrm{~kg}$ waste were then classified according to the contents. Then each type of materials in the waste content was weighed to determine the type of $R(s)$ that can be implemented to manage the waste. Also, the percentage of waste can (could) be processed through Rs has been determined.

\section{RESULT AND DISCUSSION}

\section{A. Existing System of Solid Waste Management}

According to SCC, each of the 27 words has 2 collection vans to collect solid waste from door to door. Also, some CBOs have their own collection vans. All these vans collect waste from their assigned area and take them to the secondary transfer station (STS). The waste collection rate is $66.47 \%$ as per investigation in 300 households, leaving $33.53 \%$ waste uncollected. There are 4 STSs in Sylhet City Corporation described in table 3. SCC requires no land to attune the STSs, as these are located on Government owned land.

Table 3: Location of the Secondary Transport Stations (STSs)

\begin{tabular}{|c|l|l|}
\hline $\begin{array}{c}\text { STS } \\
\text { no. }\end{array}$ & \multicolumn{1}{|c|}{ Location of STS } & $\begin{array}{l}\text { Ward } \\
\text { no. }\end{array}$ \\
\hline 1 & $\begin{array}{l}\text { Swarnashikha Road, Kadamtoli, Mouza } \\
\text { Mominkhola. }\end{array}$ & $\begin{array}{l}\text { Ward- } \\
26\end{array}$ \\
\hline 2 & $\begin{array}{l}\text { Mouza Municipality, Opposite to Mita } \\
\text { Community Center, near Allahu } \\
\text { roundabout, beside Shahi Idgah. }\end{array}$ & 17 \\
\hline 3 & $\begin{array}{l}\text { Rikabi Bazaar near Police Line, Mouza } \\
\text { Municipality. }\end{array}$ & Ward-1 \\
\hline 4 & $\begin{array}{l}\text { Near Shahid Smriti tower of MC College, } \\
\text { Mouza Raynagar. }\end{array}$ & $\begin{array}{l}\text { Ward- } \\
20\end{array}$ \\
\hline
\end{tabular}




\section{International Journal of Engineering Applied Sciences and Technology, 2021 \\ Vol. 5, Issue 10, ISSN No. 2455-2143, Pages 20-28 \\ Published Online February 2021 in IJEAST (http://www.ijeast.com)}

In STS, primary waste collection vans are emptied into containers, settled in pit(s) by gravity. An electric hoist is then used to transfer the waste into large capacity trucks provided by SCC and directly taken to Lalmatia landfill without any segregation. The overall management system undertaken by SCC is shown in Fig. 2.

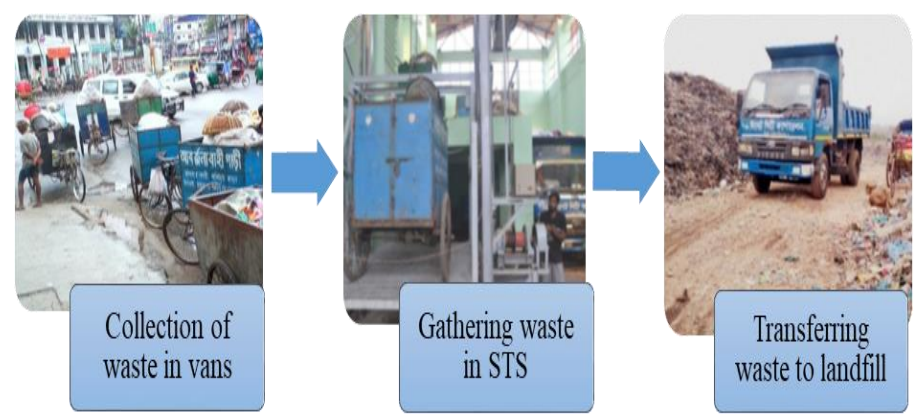

Fig. 2: Existing waste management system in SCC

\section{B. Current Practice of Waste Segregation}

It is found from the field investigation of 300 units (households, institutions, hospitals, restaurants, shops etc.) that in 204 units (about 68\%), source separation of some kinds of waste like paper and paper products, plastic bottles, broken glasses, rubbers and tires, E-wastes, metals etc. is being practiced. Other 96 units do not practise waste sorting and it is also to be mentioned that lower income families have less things to be separated than the higher income families.

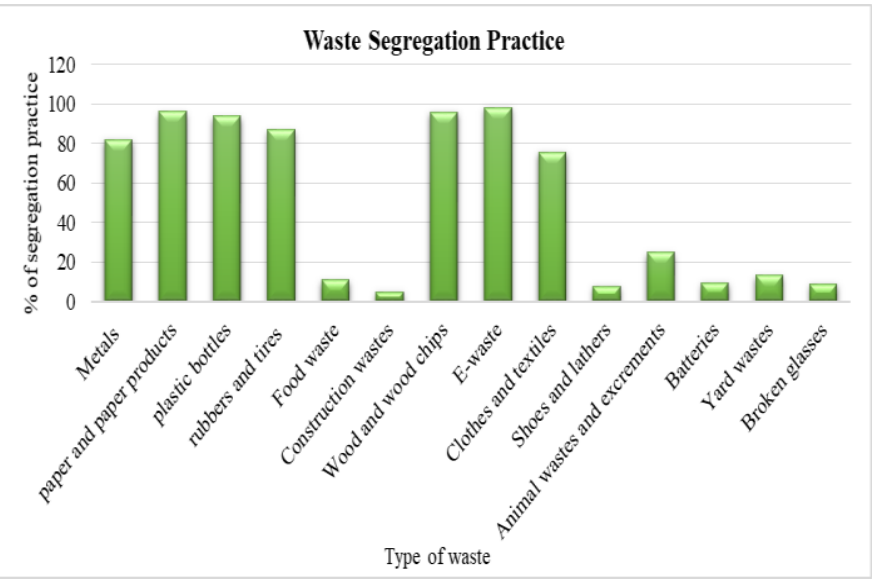

Fig. 3: Fraction of the type of waste segregated locally.

It is one of the notable findings that, people seems to separate their waste less than previous time due to the lack of space as vacant spaces are being filled up. Again, the practising 232 units separate differnet types of waste in different fraction as shown in Fig. 3.

\section{Standing Landfill Condition}

The one and only landfill site used by the SCC is situated in Lalmatia, Mogla bazar, Sylhet. Lalmatia site is about $1-15 \mathrm{ft}$. below the existing road level, fully marshy and located about 5 $\mathrm{Km}$ away from the city center. Here, some of the scavengers stealthily collect some types of waste and sell those to make their livelihood. But this kind of waste sorting is not allowed by the authority. A noticeable thing is that in the landfill, wastes are openly burnt (as shown in Fig. 4) either partially or completely to reduce the volume which is very detrimental to the environment.

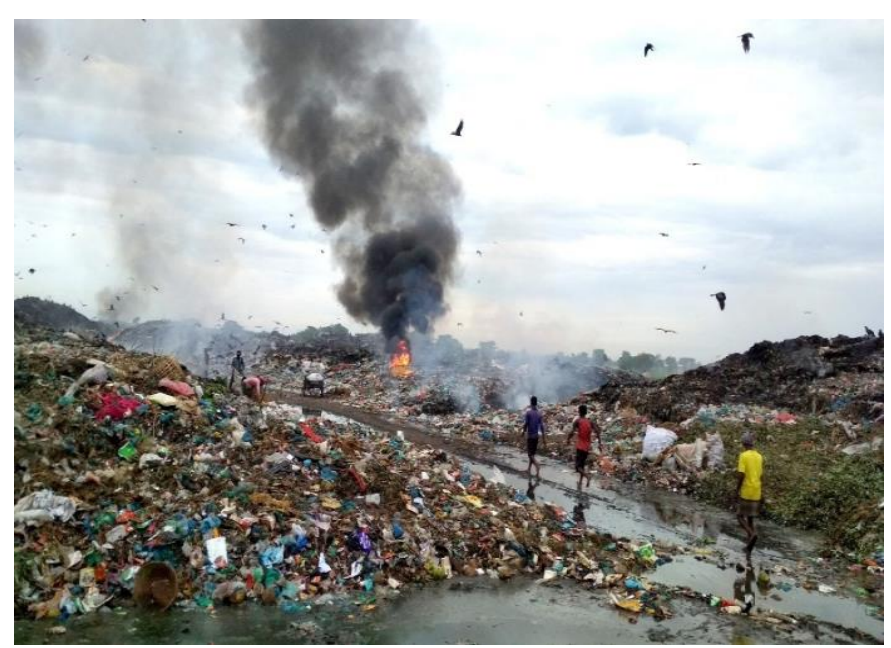

Fig. 4: Burning of waste in landfill

It is worth mentioning that, there is a separate space in Lalmatia landfill for the dumping of medical waste and some of the wastes are segregated by the workers (figure 5).

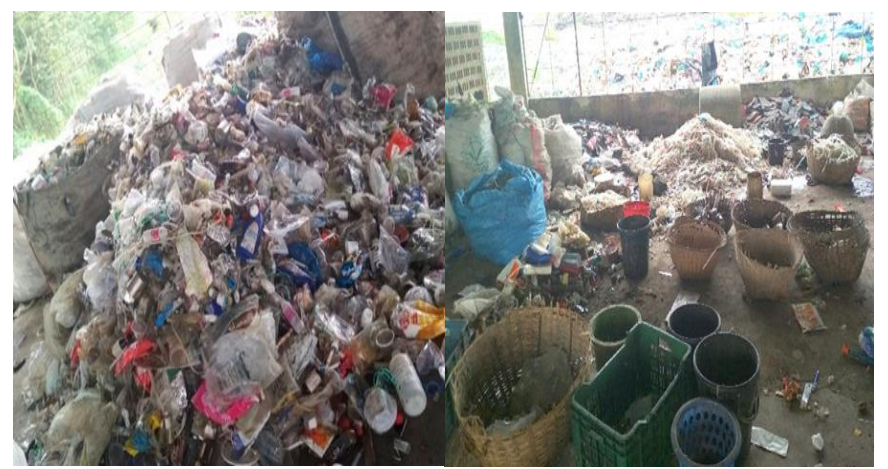

Fig. 5: Segregation of medical waste near the landfill

\section{Waste Generation Rate}

Being not an industrial city, most of the generated wastes in Sylhet are of domestic, commercial and clinical types. Daily generated waste of 300 units including households, institutions, hospitals, restaurants, shops etc. was measured and in total it was found $706 \mathrm{~kg}$ against 1476 people. On an average, it becomes $0.48 \mathrm{~kg} / \mathrm{cap} /$ day including all types of wastes.

\section{E. Correlation Test}




\section{International Journal of Engineering Applied Sciences and Technology, 2021 \\ Vol. 5, Issue 10, ISSN No. 2455-2143, Pages 20-28 \\ Published Online February 2021 in IJEAST (http://www.ijeast.com)}

To measure the strength of association in between the variables (population and solid waste) correlation test has been worked out and Pearson Correlation Coefficient (PCC) has been determined. The result have revealed that, there is high and strong association between the variables as the value of PCC is near about 1 . Table 4 shows the numerical value of the variables. In this test, pairs of variables $(n)=4$ in each computation. The solid waste amount used in this analysis is the collected waste by the Sylhet City Corporation. Due to the unavailability of generated data, total generated amount of solid waste has not been taken in this analysis.

Table 4: Variables to be correlated

\begin{tabular}{|c|c|c|}
\hline Year & Population $^{*}$ & Solid waste (tons) \\
\hline 2002 & 299679 & 90 \\
\hline 2007 & 427265 & 120 \\
\hline 2012 & 552828 & 200 \\
\hline 2017 & 782646 & 260 \\
\hline
\end{tabular}

Correlation test (Pearson Correlation Coefficient) $=0.982^{*}$ ("Correlation is significant at the 0.05 level).

\section{F. Trend Analysis}

In the last 15 years, solid waste has increased along with the increase in population as shown in table. From 2002 to 2017 , population in SCC has increased from 299679 to 782646 i.e. 482967. Again the solid waste collection by SCC is 260 tons in 2017 which was 90 tons in 2002. The trend in population and solid waste is shown in Fig. 6.

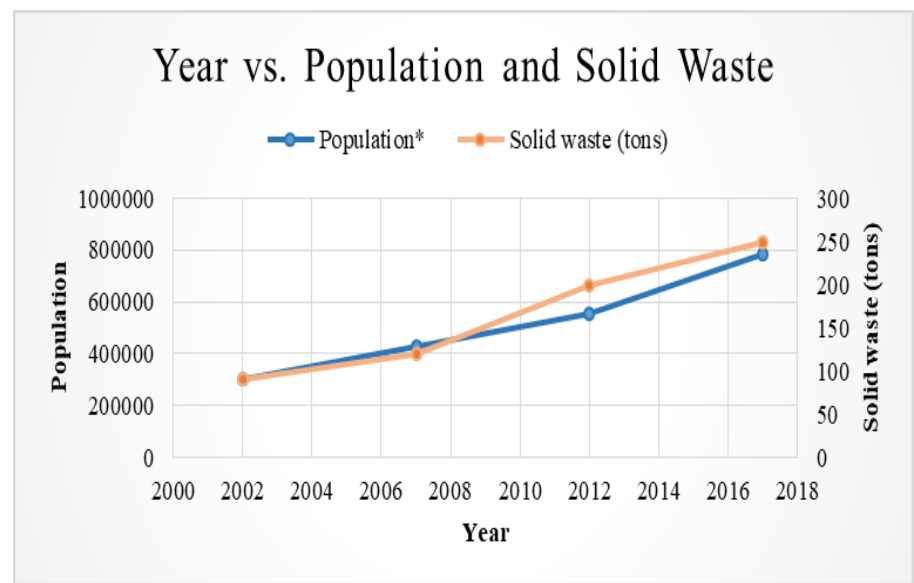

Fig. 6: Trend in population and solid waste with time

\section{G. Composition of Waste}

To determine the waste composition, $100 \mathrm{~kg}$ sample was taken 3 times from 3 trucks of wastes and the waste contents were classified according to their category. The percentages of the generated waste with the composition are shown in Fig. 7.

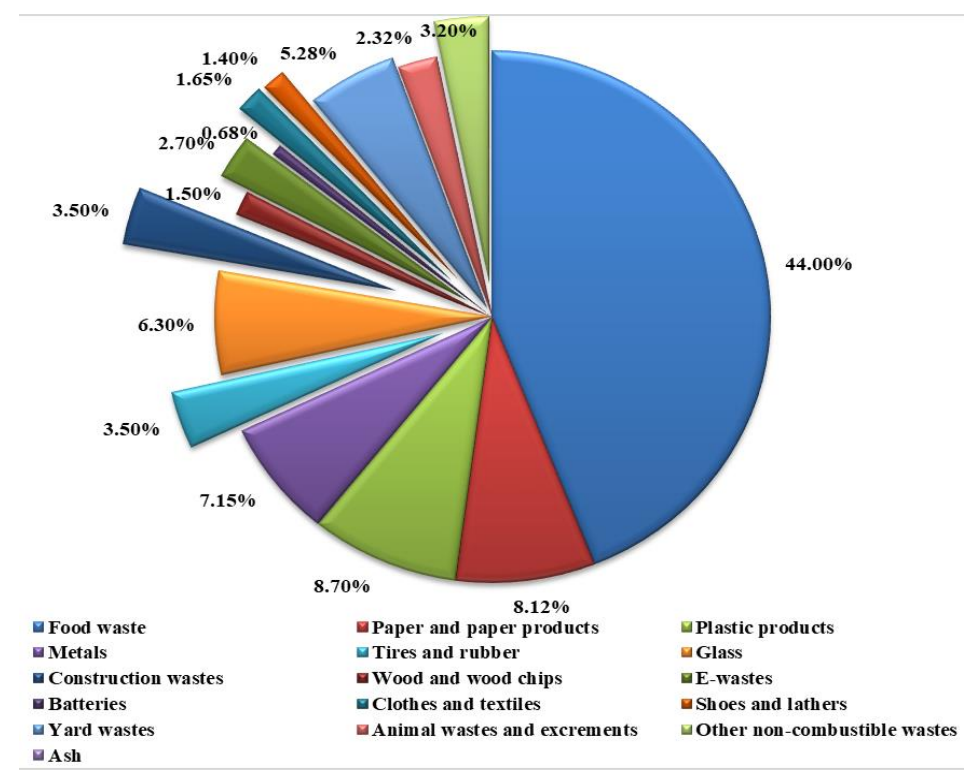

Fig. 7: Waste composition in $100 \mathrm{~kg}$ sample.

\section{H. Waste Minimization Rate through 3Rs}

In the existing management system undertaken by the SCC, there is no systematic use of 3Rs (Reduce, Reuse and Recycle). In fact, there is hardly any initiative to adopt the concept of 3Rs. But it is evident that, if this situation is continued, within a few years, a new landfill site will be required which is very difficult to find due to the increasing cost of land and public views towards the landfill. Though local hawkers collect wastes (paper, plastic, metal etc.) from door to door which is re-processed to be sold, this percentage is not significant enough. In accordance with the finding, about $72.46 \%$ of 260 tons of waste can be minimized by implementing 3Rs. As a result, each day only $27.54 \%$ i.e. 71.604 tons of wastes will need to be dumped in the landfill which will be very effective to meet the challenge of managing solid waste. Again, it has been estimated that, of the total manageable wastes (188.396 tons), $23.81 \%$ can be reduced, $15.87 \%$ can be reused and $60.32 \%$ can be recycled. The study was conducted in dry season and so the results are more valid for dry season.

\section{CONCLUSION}

The study was conducted in Sylhet city with a view to detecting the solid waste management practice and making decision on solid waste management. The study reports that Sylhet City Corporation (SCC) is losing its green cover remarkably and facing a massive urban growth. Furthermore, the study has estimated the waste generation rate in SCC as $0.48 \mathrm{~kg} / \mathrm{cap} /$ day which is approximately 376 tons per day. As waste is increasing with urban growth and it is not possible to stop urbanization, we cannot but reduce the amount of waste generation. Hence, the composition of waste as ordained calls up for source segregation and resource recovery. In fact, the 


\section{International Journal of Engineering Applied Sciences and Technology, 2021 \\ Vol. 5, Issue 10, ISSN No. 2455-2143, Pages 20-28 \\ Published Online February 2021 in IJEAST (http://www.ijeast.com)}

promotion of the $3 \mathrm{R}$ (Reduce, Reuse, Recycle) strategy is a panacea to achieve proper solid waste management in Sylhet City Corporation. The study reveals that executing the $3 \mathrm{Rs}$ with proper technology available, $72.46 \%$ of the generated waste can be minimized i.e. only $27.54 \%$ of waste is to be dumped. As a result, demand of land for waste disposal will be curtailed, environment will be availed and revenue will be added from waste recycling and resource recovery sector.

\section{REFERENCE}

1. Connett P., (2007). Zero Waste: a key move towards a sustainable society. New York. USA.

2. Damghani AM, Savarypour G, Zand E, Deihimfard R.( 2008 Jan 1). Municipal solid waste management in Tehran: Current practices, opportunities and challenges. Waste management. 28(5) (pp: 929-34)

3. Sujauddin M, Huda SM, Hoque AR., (2008 Jan 1). Household solid waste characteristics and management in Chittagong, Bangladesh. Waste management. 28(9) (pp:1688-95).

4. Tauhidur-Ur-Rahman M.(2006 Jul). Domestic waste disposal practice of Sylhet city. J. Appl. Sci.;6(7) (pp:1506-12)

5. Zurbrugg C (2002 Nov). Urban solid waste management in low-income countries of Asia how to cope with the garbage crisis. Presented for: Scientific Committee on Problems of the Environment (SCOPE) Urban Solid Waste Management Review Session, Durban, South Africa (pp:1-13).

6. Chowdhury RK., (2005). Planning for integrated storm water drainage management of the lower part of Malnichara in Sylhet city. Thesis paper .

7. Morrissey AJ, Browne J (2004 Jan 1). Waste management models and their application to sustainable waste management. Waste management.4(3): (pp:297-308).

8. Visvanathan C, Adhikari R, Ananth AP (2007 Dec). 3R practices for municipal solid waste management in Asia. Linnaeus Eco-Tech. 12 (pp:11-22).

9. Leao S, Bishop I, Evans D., (1999). Integrating urban area growth model, expert system and GIS for sustainable management of urban solid waste-a dynamic decision support system. In AURISA 99 conference proceedings: meet the challenge: 22-26 November, 1999, Fairmont Resort, Blue Mountains. Australasian Urban and Regional Information Systems Association (AURISA).

10. Leao S, Bishop I, Evans D., (2001 Nov 1). Assessing the demand of solid waste disposal in urban region by urban dynamics modelling in a GIS environment. Resources, conservation and recycling.33(4) (pp:289313).
11. Sarkar M. Eleash R., (2007). Study on various types of waste generation and their management in Dinajpur town. MS thesis. Dept. of Environmental Science, Bangladesh Agricultural University, Mymensingh.

12. Rahman M., (2011). Unplanned urbanization and hill cutting: a study on environmental change in Sylhet.

13. Vij D., (2012). Urbanization and solid waste management in India: present practices and future challenges. Procedia-social and behavioral sciences, 37. (pp:437-447).

14. Ahmed MF, Islam MS., (2014). Urbanization and environmental problem: An empirical study in Sylhet city, Bangladesh. Research on Humanities and Social Sciences. 4(3)(pp:161-72).

15. Ampofo S, Kumi E, Ampadu B., (2015). Investigating solid waste management in the Bolgatanga municipality of the Upper East region, Ghana.

16. Anilkumar PP, Chithra K., (2016 Jan 1) Land use based modelling of solid waste generation for sustainable residential development in small/medium scale urban areas. Procedia Environmental Sciences. 35 (pp:229-37).

17. Norbu T, Visvanathan C, Basnayake B., (2003). Pilot scale study on pretreatment of municipal solid waste proir to landfilling. Workshop on Sustainable Landfill Management.

18. Vidanaarachchi CK, Yuen ST, Pilapitiya S., (2006 Jan 1). Municipal solid waste management in the Southern Province of Sri Lanka: Problems, issues and challenges. Waste Management. 26(8) (pp:920-30).

19. Tinmaz E, Demir I., (2006 Jan 1). Research on solid waste management system: to improve existing situation in Corlu Town of Turkey. Waste management.26(3) (pp:307-14).

20. Chattopadhyay S, Dutta A, Ray S., (2009 Apr 1). Municipal solid waste management in Kolkata, India-A review. Waste Management. 29(4) (pp:144958).

21. Troschinetz AM, Mihelcic JR., (2009 Feb 1). Sustainable recycling of municipal solid waste in developing countries. Waste management.29(2) (pp:915-23).

22. Periathamby A, Hamid FS, Khidzir K., (2009 May). Evolution of solid waste management in Malaysia: impacts and implications of the solid waste bill, 2007. Journal of material cycles and waste management. 11(2) (pp:96-103).

23. Abd Manaf L, Samah MA, Zukki NI., (2009 Nov 1). Municipal solid waste management in Malaysia: Practices and challenges. Waste management. 29(11) (pp:2902-6).

24. Smyth DP, Fredeen AL, Booth AL., (2010 Sep 1). Reducing solid waste in higher education: The first 


\section{International Journal of Engineering Applied Sciences and Technology, 2021 \\ Vol. 5, Issue 10, ISSN No. 2455-2143, Pages 20-28 \\ Published Online February 2021 in IJEAST (http://www.ijeast.com)}

step towards 'greening'a university campus. Resources, Conservation and Recycling. 54(11) (pp:1007-16).

25. Sakai SI, Yoshida H, Hirai Y, Asari M, Takigami H, Takahashi S, Tomoda K, Peeler MV, Wejchert J, Schmid-Unterseh T, Douvan AR., (2011 Aug 1). International comparative study of $3 \mathrm{R}$ and waste management policy developments. Journal of Material Cycles and Waste Management. 13(2) (pp:86-102).

26. Hashim KS, Mohamed AH, Redza HZ., (2017 Sep 18). Developing a waste minimization awareness model through community based movement: A case study of the IIUM Green Team. Geografia-Malaysian Journal of Society and Space. 8(5).

27. Peprah K, Amoah ST, Achana GT., (2015). Assessing '3rs'model in relation to municipal solid waste management in wa, ghana. Faculty of Integrated Development Studies.

28. Adeniran AE, Nubi AT, Adelopo AO., (2017 Sep 1). Solid waste generation and characterization in the University of Lagos for a sustainable waste management. Waste Management. 67 (pp:3-10).

29. Masur YV, Salunke RS., (2017). Waste Disposal Methods followed by the Residents of Dharwad City. International Journal of Pure Applied Bioscience, 5(3). (pp:553-558).

30. Chanhthamixay B, Vassanadumrongdee S, Kittipongvises S., (2017 Nov 23). Assessing the sustainability level of municipal solid waste management in Bangkok, Thailand by wasteaware benchmarking indicators. Applied Environmental Research. 39(3) (pp:49-61).

31. Mobarak MH, Bhuiyan A., (2009). Solid Waste Minimization through Rs: A case study of Bangladesh. B.Sc. thesis. Shahjalal University of Science and Technology.

32. Moriom HA, Mahmud MI, Iqbal SA, Sarker NC., (2012). Clinical Waste Management in Sylhet City, Bangladesh. SUST Journal of Science and Technology 19(5). (pp: 8-13).

33. Chowdhury MAI., (2013). Municipal Solid Waste Management. Dhaka: University Grants Commission of Bangladesh.

34. Chowdhury RB, Sujauddin M, Murakami S, Chakraborty P, Alam MS., (2013 Jan 1). Current status of municipal solid waste management system in Chittagong, Bangladesh. International Journal of Environment and Waste Management. 12(2) (pp:16788).

35. Ivy N, Uddin MM, Hossain MK., (2013). People's perception on using waste bins in reduce, reuse and recycle (3Rs) process for solid waste management (SWM) in Chittagong, Bangladesh. International
Journal of Applied Science, Technology and Engineering Research. 2(3) (pp:30-40).

36. Yousuf TB. 3R (Reduce, Reuse and Recycle) in Bangladesh. Municipal Solid Waste Management in Asia and the Pacific Islands 2014. (pp. 61-75). Springer, Singapore.

37. Chowdhury AH, Mohammad N, Haque MR, Hossain T., (2014). Developing 3Rs (reduce, reuse and recycle) strategy for waste management in the urban areas of Bangladesh: Socioeconomic and climate adoption mitigation option. IOSR Journal of Environmental Science, Toxicology and Food Technology (IOSR-JESTFT). 8(5) (pp:9-18).

38. Islam FS., (2016 Sep). Solid waste management system in Dhaka City of Bangladesh. Journal of Modern Science and Technology. 4(1) (pp:192-209).

39. Yasmin S, Rahman MI., (2017 Mar). A review of solid waste management practice in Dhaka City, Bangladesh. International Journal of Environmental Protection and Policy. 5(2) (pp:19-25).

40. Islam MA, Hossain MS, Islam MT, Iqbal Salma A., (2017). Municipal Solid Waste Management in Sylhet city, Bangladesh. In I. R. Md. Alamgir (Ed.), WasteSafe 2017. Proceedings of the WasteSafe 2017 - 5th International Conference on Solid Waste Management in South Asian Countries. Khulna, Bangladesh.

41. Hossain MS, Shehab MM, Islam MR, Shah MS, Pal SK., (2018). Review on solid waste management process and environmental impact due to solid waste in Sylhet City Corporation, Bangladesh. International Journal of Environment and Waste Management. 22(1-4) (pp:296-306).

42. Mamun MR, Lovely SJ, Akther S., (2018). Challenges of solid waste management in Sylhet City Corporation. J. Sylhet Agril. Univ. 5(2) (pp:213-222).

43. Islam MN (2015). An Introduction to Research Methods, (3rd rev. ed.). Dhaka: Mullick \& brothers. 